\title{
Study on Graphite Powder as Conductive Pigments for Impressed Current Cathodic Protection System using Carbon Fiber Reinforced Polymer Anode
}

\author{
Wijaya, G.B. ${ }^{*}$, Lays, D.P.1, Tanto, H.H.1, Tjandra, D. ${ }^{1}$
}

\begin{abstract}
The use of Carbon Fiber Reinforced Polymer (CFRP), for both strengthening material and anode for Impressed Current Cathodic Protection (ICCP) system, is being investigated. The focus of this study is to develop the epoxy that has good bond strength and electrical conductivity. Graphite powder is used as conductive pigments with percentage ranges from $7.5 \%$ to $17.5 \%$. All specimens were partially submerged in $5 \% \mathrm{NaCl}$ solution and induced with electrical current of $10 \mathrm{~mA} / \mathrm{m}^{2}$ and $20 \mathrm{~mA} / \mathrm{m}^{2}$ for 30 days. An average potential increase of $200 \mathrm{mV}$ was recorded using half cell potential test. The application of 30 days ICCP up to current density of $20 \mathrm{~mA} / \mathrm{m}^{2}$ did not affect the bond strength significantly and still complies with ACI recommendation. However, graphite content of more than $15 \%$ are found to be not workable and the bond strength is greatly reduced to less than $1 \mathrm{MPa}$ This study concluded that the recommended graphite powder content shall be in the range of $10 \%$ to $15 \%$.
\end{abstract}

Keywords: Carbon fiber reinforced polymer laminate; graphite powder; half cell potential; impressed current cathodic protection system; pull-off test.

\section{Introduction}

Reinforced concrete structure when exposed to aggressive environment tends to suffer from deterioration due to reinforcement corrosion. When not treated well, this will lead to strength loss and subsequently structural failure. Externally bonded Carbon Fiber Reinforced Polymer (CFRP) laminate has been used as an effective strengthening system. In this regard, Epoxy plays the most critical role to transfer the strain from the concrete substrate to the CFRP laminate.

US Federal Highway Administration (FHWA) stated that Cathodic Protection is the only rehabilitation technique that has been proven to stop corrosion in salt contaminated bridge deck regardless of the chloride content of the concrete [1]. To protect the steel reinforcement, an external anode is connected and induced by electrical current. Other than Titanium, Carbon is also a good material to be used as Anode. For CFRP laminate to be used as anode, the epoxy needs to be conductive enough to pass the current.

${ }^{1}$ Department of Civil Engineering, Petra Christian University, J. Siwalankerto 121-131, Surabaya 60236, INDONESIA.

*Corresponding author; email: gunawanbw@petra.ac.id

Note: Discussion is expected before November, $1^{\text {st }} 2019$, and will be published in the "Civil Engineering Dimension", volume 22, number 1, March 2020.

Received 29 August 2019; revised 15 September 2019; accepted 20 September 2019.
Since epoxy itself is an insulator material, many researches [2-5] were conducted to develop a conductive epoxy with good bond strength to ensure that the externally bonded CFRP laminate can serves well as both strengthening and corrosion protection system.

\section{Literature Review}

\section{Steel Rebar Corrosion Mechanism}

In general, steel rebar in reinforced concrete are protected by the passive layer provided by the concrete cover, which is having high alkalinity $(\mathrm{pH}$ 11-13). Carbonation and Chloride ingress from the environment lowers the $\mathrm{pH}$ of concrete causing the passive layer to be damaged. When the $\mathrm{pH}$ is reduced to as low as 9.8, corrosion starts to occur. As shown in Figure 1, corrosion is an electrochemical reaction between anode and cathode. The steel at the anodic zone will reacts with water and oxygen and produce Ferrous Hydroxide (rust), which can grow its volume up to six times. This generates additional tensile stress to the surrounding concrete. When the tensile stress exceeds the concrete tensile capacity, the concrete will crack, delaminate, and subsequently spall. Cracks make water, oxygen, and chloride ion to penetrate more, causing the corrosion process to escalate faster. The parent steel cross section reduced and the bond to the concrete weakened, causing strength loss to the structure, which may lead to structural failure [6]. 

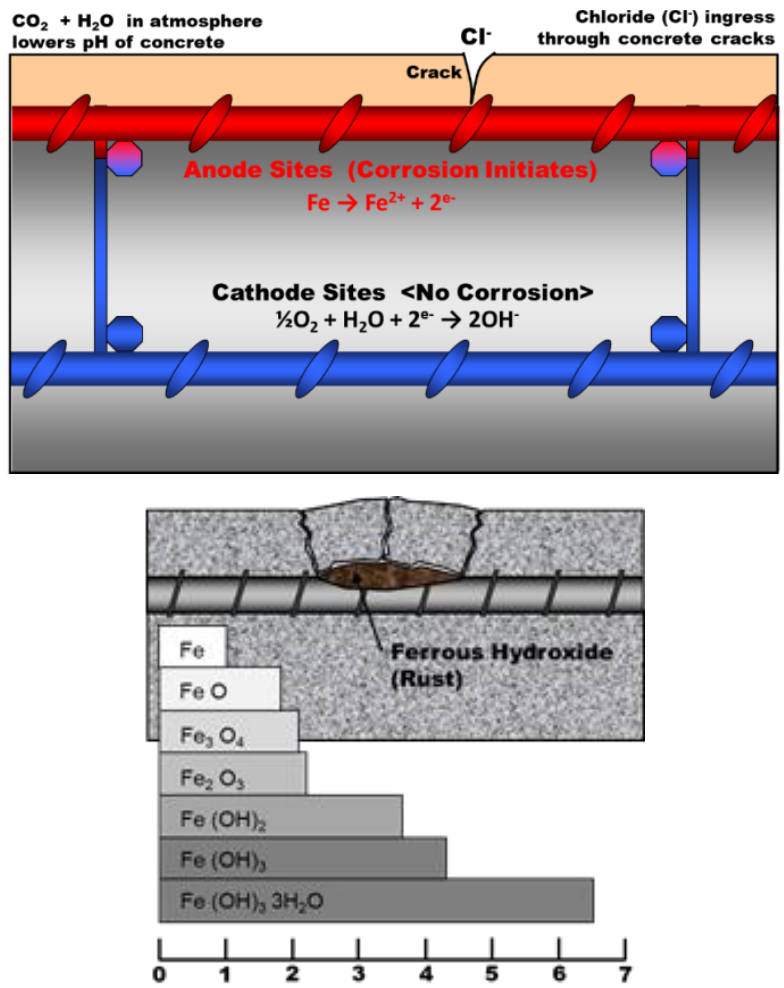

Figure 1. Steel Rebar Corrosion Mechanism

\section{Impressed Current Cathodic Protection (ICCP)}

In principal, the Impressed Current Cathodic Protection system lower down the steel potential to be more negative than its corrosion potential, reduce the potential difference between the anode and cathode so that the corrosion rate is reduced to the smallest value. This is achieved by inducing a Direct Current (DC) to the steel reinforcement. The positive and negative pole of the DC Power Supply are connected to the CFRP Anode and Steel Reinforcement, respecttively as shown in Figure 2. The electrical current will make all the steel reinforcement to be cathode, thus corrosion will not happen at the steel reinforcement. Since concrete has relatively high resistivity, the choice of anode and current density is very important in designing the ICCP system to ensure the steel reinforcement are receiving sufficient protection [7].

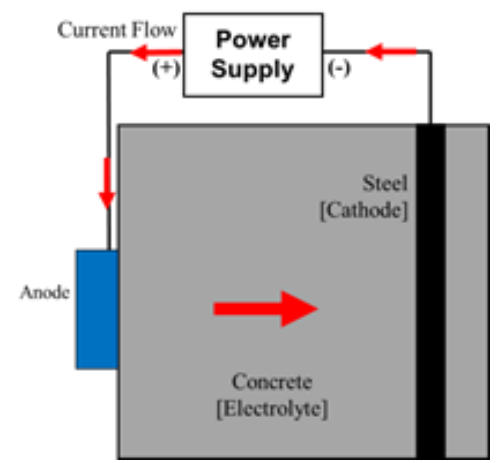

Figure 2. ICCP Scheme for Reinforced Concrete
CFRP laminate is commonly used as structural strengthening material for reinforced concrete structure. CFRP has electrical conductivity properties and is more reactive compared to steel, which make it possible to be used as Anode for ICCP. It also has a good chemical and corrosion resistance which is suitable to be used in corrosive environments. The epoxy used to bond the CFRP laminate need to be modified as it is an insulator. Graphite powder is one of the conductive pigments that can be added to the epoxy to increase its conductivity. However, adding too much graphite can reduce the epoxy workability and bond strength [2-5].

The current density induced needs to be designed within the desirable range. The steel reinforcement will not have sufficient protection if the current density is too small. However too much current density will generate Hydrogen gas on the steel surface, which lower the steel bond strength to the concrete [7]. BS EN 12696:2012 recommends a current density of $2-20 \mathrm{~mA} / \mathrm{m}^{2}$ of steel surface for ICCP application on reinforced concrete [8].

\section{Half Cell Potential Test}

The effectiveness of the ICCP system is measured using Half Cell Potential Test (ASTM C876) [9]. The test is done by measuring the potential difference between the steel reinforcement to the standard reference electrode as shown in Figure 3. The potential reading $(\mathrm{mV})$ indicates the likelihood of the corrosion. The more negative potential reading indicates the steel more likely will suffer from corrosion.

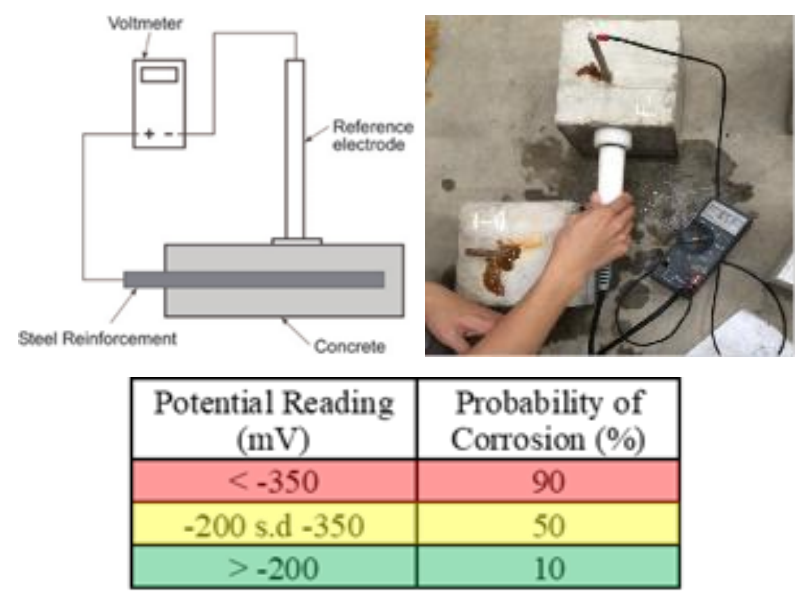

Figure 3. Half Cell Potential Test Scheme

\section{Pull-Off Test}

The bond strength between CFRP laminate and concrete after the ICCP is measured using Pull-off test (ASTM C1583) [10]. ACI 440.2R.17 recommends a minimum bond strength of 1.4MPa for externally bonded FRP application. The failure mode of this test shall be on the concrete substrate [11]. The Pull off Test Scheme is as shown in Figure 4. 

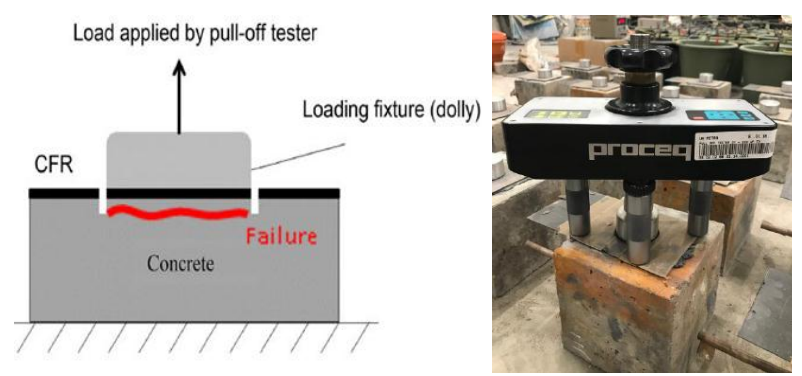

Figure 4. Pull-off Test Scheme

\section{Research Method}

The test set up for this research is shown in Figure 5. A total of 84 reinforced concrete specimens ( $f_{c}^{\prime} 23$ $\mathrm{MPa})$ were cast with configuration as shown in Figure 5a. Polytetrafluoroethylene (Teflon) tape was attached at the bottom and top of the steel reinforcement to ensure the corrosion to occur only at the middle $100 \mathrm{~mm}$ section embedded in the concrete. All specimens were then water cured.

After 28 days, initial corrosion was induced to simulate the actual condition of reinforced concrete with corroded steel reinforcement. As shown in Figure 5b. the steel reinforcement and an external stainlesssteel rod were connected to the positive and negative pole of DC Power supply, respectively. The specimen was partially submerged to $5 \% \mathrm{NaCl}$ solution with the top of the specimens were kept above the $\mathrm{NaCl}$ solution. An electrical current of $64 \mathrm{~mA}$ was given for 166 hours as an initial corrosion.

Before the CFRP laminate was applied, the concrete specimen is dried and cleaned. CFRP laminate was then bonded to the specimen with the configuration shown in Figure 5c. Graphite content of 7.5\%, 10\%, $12.5 \%, 15 \%$, and $17.5 \%$ was added to the Epoxy to improve its conductivity.

All specimens were then partially submerged again to $5 \% \mathrm{NaCl}$ solution. The positive and negative poles of DC Power supply are connected to steel reinforcement and CFRP laminate, respectively as shown in Figure 5d. Current density of 10 and $20 \mathrm{~mA} / \mathrm{m}^{2}$ were induced for 30 days. The electrical current will flow from CFRP Laminate (Anode) to steel reinforcement (Cathode).

The steel reinforcement potential was measured using the $\mathrm{Ag} / \mathrm{AgCl} / 0.5 \mathrm{M} \mathrm{KCl}$ reference electrode and a digital voltmeter in 5 days interval. The reading was obtained 24 hours after the power supply was turned off to ensure the steel has been polarized properly. At the end of 30 days, pull off test were conducted on all specimens, to measure the remaining bond strength.

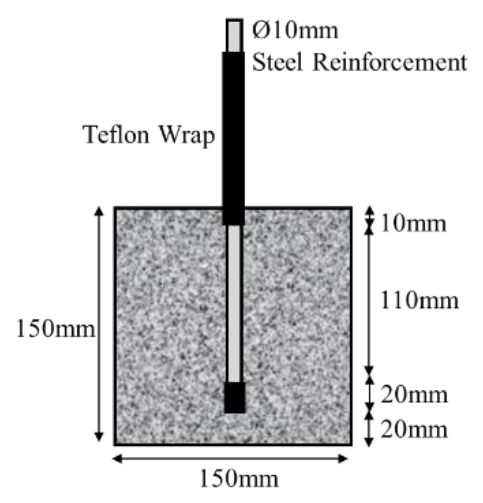

Figure 5a. Reinforced Concrete Specimen

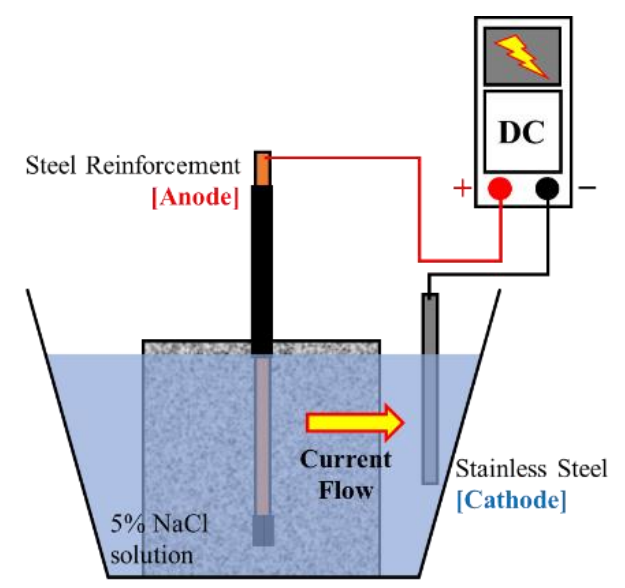

Figure 5b. Initial Corrosion Process

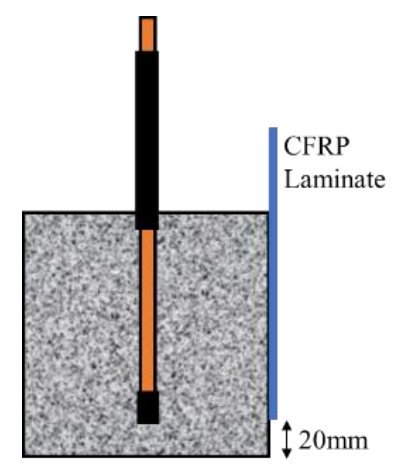

Figure 5c. FRP Application

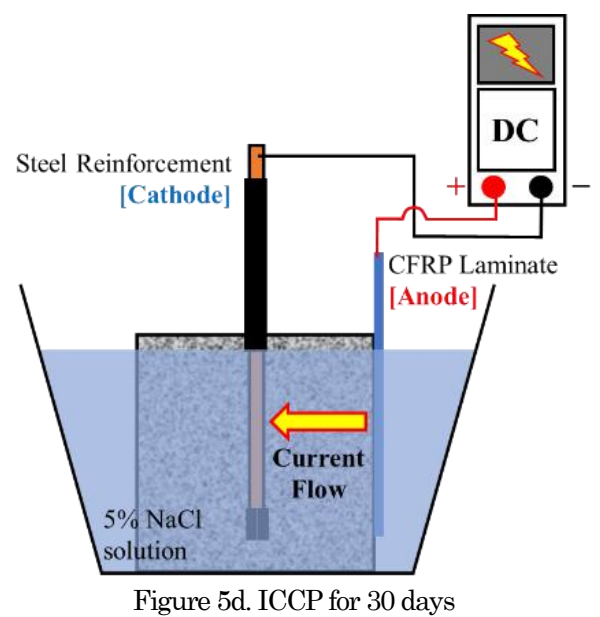

Figure 5. Test Set Up 


\section{Results and Discussions}

Half Cell potential test was conducted before and after Initial Corrosion was given. The potential reading and typical visual appearance after initial corrosion are given in Figure 6. The average potential reading before and after initial corrosion is $-215 \mathrm{mV}$ and $-688 \mathrm{mV}$, respectively. After initial corrosion, all specimens are in the $90 \%$ corrosion probability zone based on ASTM C876 criteria, which is confirmed visually.

The potential reading during 30 days ICCP are presented in Figure 7. For both 10 and $20 \mathrm{~mA} / \mathrm{m}^{2}$ current density, all specimens are shown to have more positive potential reading. This indicates that ICCP has successfully lowered the corrosion probability as per ASTM C876 criteria. However, the amount of improvement given by both current densities have no significant difference since both are still within the $90 \%$ corrosion probability zone.

The potential increase after 30 days ICCP compared to the initial potential reading for each graphite content is presented in Figure 8. For both current densities, the influence of graphite content exhibit the same pattern with $12.5 \%$ to be the optimum. The maximum potential increase given by the ICCP is $221 \mathrm{mV}$ and $196 \mathrm{mV}$ for current density of 10 $\mathrm{mA} / \mathrm{m}^{2}$ and $20 \mathrm{~mA} / \mathrm{m}^{2}$, respectively. ASTM C876-15 stated that steel with potential difference of $+20 \mathrm{mV}$ may be considered to be in the same corroded condition, thus for each graphite content the amount of protection given by both current densities are relatively the same. The graphite contents of between $7.5 \%$ to $17.5 \%$ didn't have a significant impact on the effectiveness of ICCP system, as the measured potential increase ranged from $192-221 \mathrm{mV}\left(10 \mathrm{~mA} / \mathrm{m}^{2}\right)$ and $177-196 \mathrm{mV}\left(20 \mathrm{~mA} / \mathrm{m}^{2}\right)$.

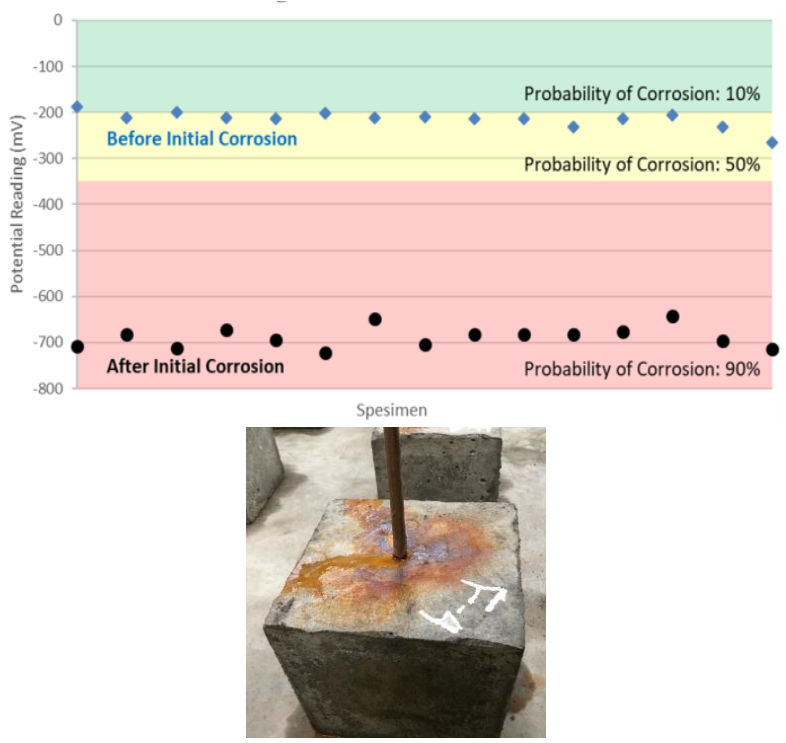

Figure 6. Potential Reading and Typical Visual Appearance After Initial Corrosion

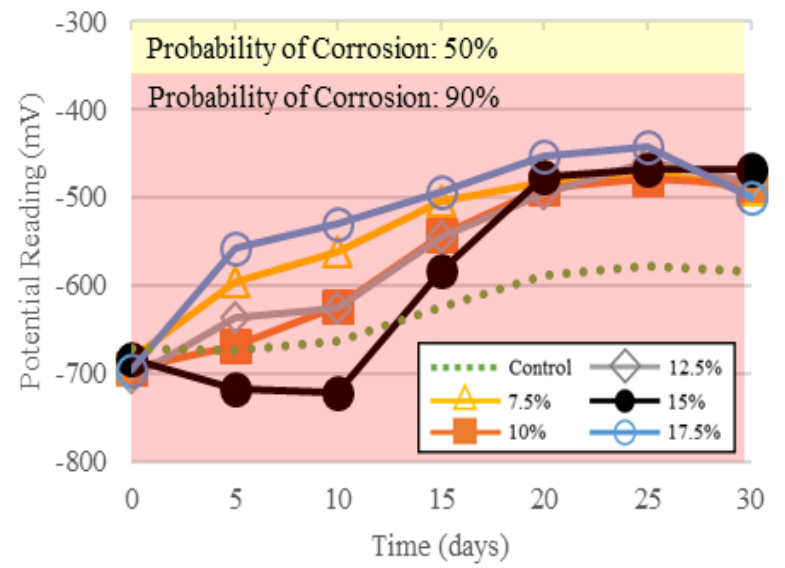

(a)

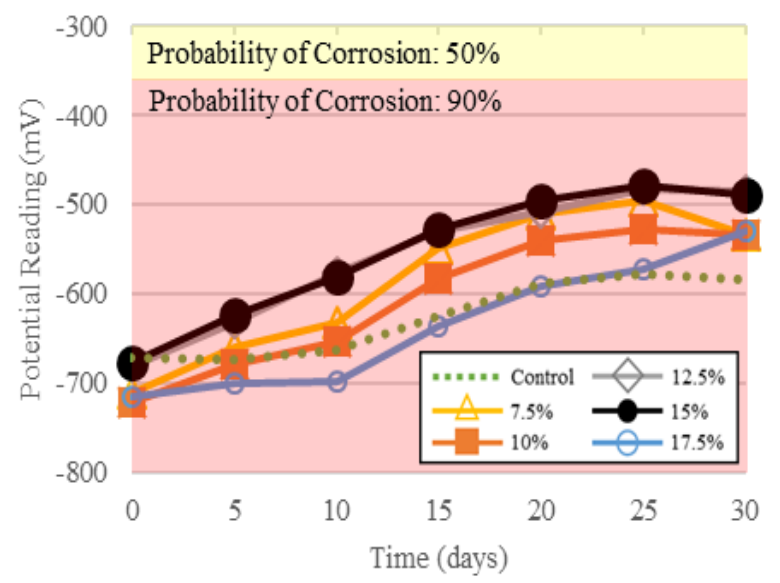

(b)

Figure 7. Potential Reading During 30 Days ICCP for Current Density of (a) $10 \mathrm{~mA} / \mathrm{m}^{2}$ and (b) $20 \mathrm{~mA} / \mathrm{m}^{2}$

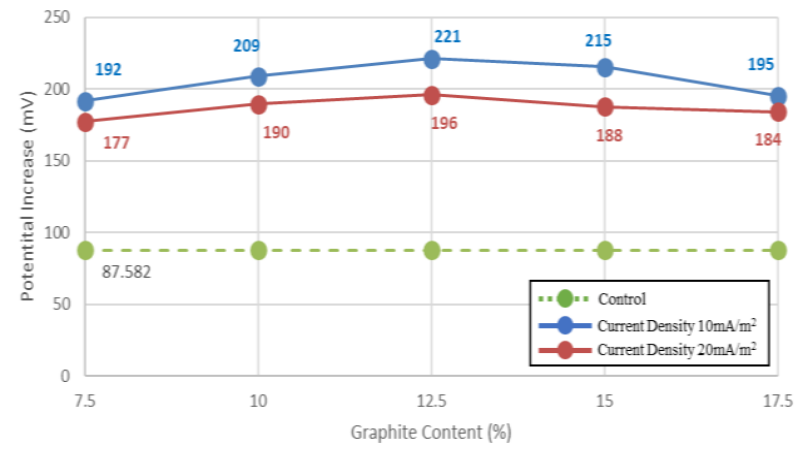

Figure 8. Potential Increase after 30 Days ICCP

The result of pull off test is presented in Figure 9. The specimens with graphite content of $7.5 \%-15 \%$ have bond strength between $2.36 \mathrm{MPa}$ to $2.76 \mathrm{MPa}$ and the failure is on the concrete. These meet the requirements given by ACI 440.2R-17 of $1.4 \mathrm{MPa}$. All specimens with $17.5 \%$ graphite content are considered fails as the bond strength is less than 1 $\mathrm{MPa}$ and the failure is on either epoxy-concrete or epoxy-FRP surface as shown in Figure 10. Both 10 and $20 \mathrm{~mA} / \mathrm{m}^{2}$ current densities did not show significant difference in all specimen's bond strength compared to the control specimens (no ICCP). 


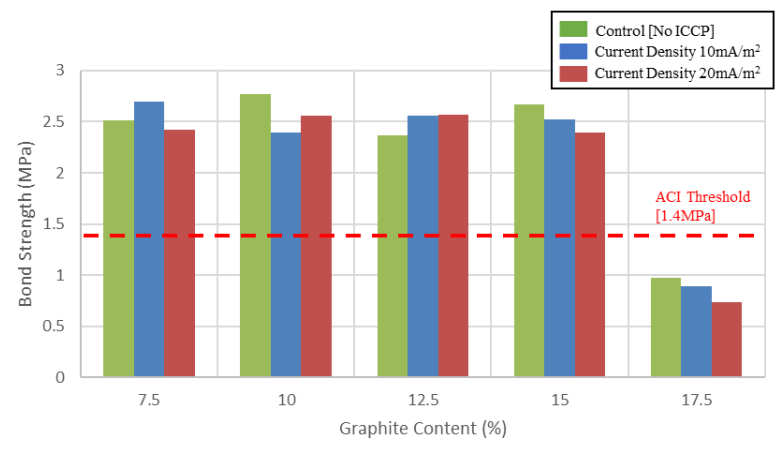

Figure 9. Pull Off Test Results after 30 Days ICCP

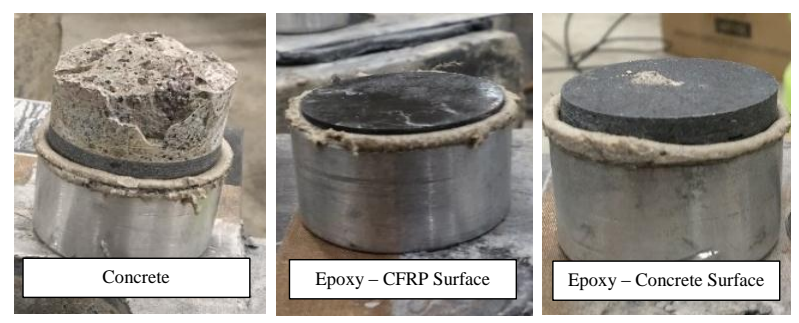

Figure 10. Typical Specimen Failure (a) Concrete Failure; (b) Epoxy-CFRP Surface Faliure; (c) Epoxy-Concrete Surface Failure

\section{Conclusion}

1. Graphite powder can be used to make the epoxy conductive. The use of CFRP laminate as ICCP anode has been found to lower the corrosion probability. For graphite content ranges from $7.5 \%$ to $17.5 \%$, both 10 and $20 \mathrm{~mA} / \mathrm{m}^{2}$ provides similar potential increase. This indicates that increasing the current density of more than 10 $\mathrm{mA} / \mathrm{m}^{2}$ will not give any improvement. The optimum graphite content is $12.5 \%$, giving an average potential increase of $200 \mathrm{mV}$.

2. All specimens with graphite content up to $15 \%$ still have a bond strength of more than 2.3MPa, which is well above the $1.4 \mathrm{MPa}$ as recommended by ACI. The application of 30 days ICCP up to current density of $20 \mathrm{~mA} / \mathrm{m}^{2}$ did not affect the bond strength significantly compared to the control specimen without ICCP. However, graphite content of more than $15 \%$ are found to be not workable and the bond strength is greatly reduced to less than $1 \mathrm{MPa}$.

3. Based on this research, for an effective ICCP system using CFRP laminate as anode, the recommended graphite content to be added shall be in the range of $10 \%-15 \%$.

\section{Acknowledment}

The authors would like to acknowledge the hard work of Kevin and Grace Christiani Linggadiharja in this research. The authors would also like to thank SIKA Indonesia for the supply of Sika Carbodur ${ }^{\circledR}$ CFRP Laminate and Epoxy used in this research.

\section{References}

1. FHWA-RD-096, Long Term Effectiveness of Cathodic Protection Systems on Highway Structures, Federal Highway Administration Research and Development, McLean, VA, USA, 2001.

2. Gadve, S., Mukherjee, A., and Malhotra, S.N., Active Protection of Fiber-reinforced Polymerwrapped Reinforced Concrete Structures Against Corrosion, Corrosion, 67(2), 2011, pp. 25002-25011.

3. Lu, Y., Hu, J., Li, S., and Tang, W., Active and Passive Protection of Steel Reinforcement in Concrete Column Using Carbon Fibre Reinforced Polymer Against Corrosion. Electrochimica Acta. Vol. 278, 2018, pp. 124-136. https://doi. org/10.1016/j.electacta.2018.05. 037

4. Nguyen, C.V., Mangat, P.S., Lambert, P., O'Flaherty, F.J., and Jones, G., Dual Function Carbon Fibre Reinforced Anode System for Concrete Structures. Materials and Structures. 48(7), 2014, 2157-2167. https://doi.org/10.1617/ s11527-014-0300-0

5. Bahekar, P.V., and Gadve, S.S., Impressed Current Cathodic Protection of Rebar in Concrete Using Carbon FRP Laminate. Construction and Building Materials, 156, 2017, pp. 242-251. https://doi.org/10.1016/j.conbuildmat.2017. 08.145

6. Broomfield, J.P., Corrosion of Steel in Concrete: Understanding, Investigation and Repair, Second Edition, CRC Press, London, UK, 2006.

7. Wilson, K., Jawed, M., and Ngala, V., The selection of Cathodic Protection Systems for the repair of Reinforced Concrete Structures, Construction and Building Materials, Elsevier, 39, 2013, pp. 19-25,

8. British Standards Institution, BSI Standards Publication Cathodic Protection of Steel in Concrete (ISO 12696: 2012). United Kingdom: BSI Standards Limited, 2012.

9. ASTM C876, Standard Test Method for HalfCell Potentials of Uncoated Reinforcing Steel in Concrete, ASTM International, West Conshohocken, PA., USA, 2015.

10. ASTM C1583, Standard Test Method for Tensile Strength of Concrete Surfaces and Bond Strength or Tensile Strength of Concrete Repair and Overlay Materials by Direct Tension (PullOff Method), ASTM International, West Conshohocken, PA., USA, 2013.

11. ACI 440.2R, Guide for the Design and Construction of Externally Bonded FRP Systems for Strengthening Concrete Structures, ACI Committee 440, Farmington Hills, MI., USA, 2017.

12. Ahmad, S., Techniques for Inducing Accelerated Corrosion of Steel in Concrete. Arabian Journal for Science and Engineering, 34(2), 2009, pp. 95104. 